\title{
MENJADI ISTRI DIPLOMAT: HURUSTIATI SOEBANDRIO DALAM MEMBENTUK CITRA INDONESIA DI INGGRIS 1947-1954
}

\author{
BECOMING THE "LADY DIPLOMAT”: \\ HURUSTIATI SOEBANDRIO IN FORMING INDONESIA'S \\ IMAGE IN THE UNITED KINGDOM 1947-1954
}

\author{
Ayu Wulandari \\ Departemen Ilmu Sejarah Universitas Gadjah Mada \\ Jln. Sosiohumaniora, Bulaksumur, Yogyakarta, Indonesia \\ ayuwulandari99@mail.ugm.ac.id
}

Diterima tanggal 15 Desember 2020

Disetujui tanggal 25 November 2021

\begin{abstract}
In the history of Indonesian diplomacy, there have been several outstanding diplomat figures who have made achievements, such as Soebandrio. Then, it is important to realize that the success of Soebandrio in connecting Indonesia with the world when he was in London and Moscow; and his role in various significant state missions cannot be apart from his wife's role, Hurustiati Soebandrio. During Soebandrio's career, Hurustiati's diplomatic role began when her husband became the Indonesian Ambassador in London, at least from 1947 to 1954. During that time, Hurustiati took part in various efforts to build a good image of Indonesia to support the implementation of foreign policy. This study focuses on examining the role of Hurustiati Soebandrio as a wife of a diplomat from 1947 to 1954. Therefore, the study aims to present the role of women as diplomatic wives in the writing of the history of Indonesian diplomacy. In general, it also aims to encourage the writing of a history of diplomacy that pays attention to the role of women. This study employed the historical method by placing archives, magazines, and newspapers as primary sources. The study shows three images of Indonesia that Hurustiati formed in London, namely Indonesia as an independent country, a country that try to reach gender equality, and a multicultural county. To achieve these three images, Hurustiati made various efforts, such as giving official lectures, holding talks with diplomatic officials and their wives, and initiating exhibitions.
\end{abstract}

Keywords: diplomacy, foreign policy, image of Indonesia, and 'lady diplomat'.

\begin{abstract}
ABSTRAK
Dalam perjalanan sejarah diplomasi Indonesia, terdapat beberapa tokoh diplomat ulung yang menorehkan prestasi, seperti Soebandrio. Kemudian, perlu disadari bahwa keberhasilan Soebandrio dalam menghubungkan Indonesia dengan dunia luar melalui London dan Moskow, hingga perannya dalam berbagai misi penting negara tidak dapat dilepaskan dari peran istrinya, Hurustiati Soebandrio. Selama karir Soebandrio, peran diplomatik Hurustiati terlihat ketika suaminya ditugaskan sebagai Duta Besar Indonesia di London, setidaknya
\end{abstract}


sejak 1947 hingga 1954. Dalam kurun waktu tersebut, Hurustiati turut melakukan berbagai upaya untuk membentuk citra baik Indonesia untuk mendukung pelaksanaan politik luar negeri. Oleh karena itu, penelitian ini berfokus mengkaji peran Hurustiati Soebandrio sebagai istri diplomat sejak 1947 sampai 1954. Kajian ini bertujuan untuk menghadirkan peran perempuan sebagai istri diplomat dalam penulisan sejarah diplomasi Indonesia. Secara lebih luas, kajian ini juga bertujuan untuk mendorong penulisan sejarah diplomasi yang turut memperhatikan peran kaum perempuan. Kajian ini dilakukan menggunakan metode sejarah dengan menempatkan arsip, majalah, dan surat kabar sebagai sumber primer. Kajian menunjukkan ada tiga citra Indonesia yang dibentuk oleh Hurustiati di London, yakni Indonesia sebagai negara merdeka, negara berupaya memperjuangkan kesetaraan gender, serta negara yang multikultural. Untuk mencapai ketiga citra tersebut, Hurustiati melakukan berbagai upaya, seperti memberikan ceramah secara resmi, melakukan perbincangan dengan para pejabat diplomatik dan istrinya, dan menginisiasi pameran.

Kata kunci: diplomasi, politik luar negeri, citra Indonesia, dan istri diplomat.

\section{A. PENDAHULUAN}

Pada abad ke-20, kaum perempuan memainkan peranan penting dalam politik luar negeri dan diplomasi. Bagi negara-negara yang baru merdeka pasca-Perang Dunia II, kaum perempuan juga menjadi bagian yang tidak terkecualikan dalam pelaksanaan politik luar negeri dan diplomasi. Terutama bagi negara-negara di Asia dan Afrika, termasuk Indonesia, yang memiliki sejarah panjang persentuhan perempuan dengan negara. ${ }^{1}$ Sayangnya, peranan kaum perempuan tersebut tidak mendapatkan perhatian dari

\footnotetext{
${ }^{1}$ Di Asia dan Afrika, kaum perempuan menjadi bagian penting dalam pembentukan negara. Mereka tergabung dalam organisasi atau gerakan perempuan untuk menghancurkan kekuatan kolonial. Karenanya, kaum perempuan memiliki hubungan dekat dengan negara bahkan ketika sudah merdeka. Lebih lanjut dapat dilihat di: Elisabeth Armstrong, "Before Bandung: The Anti-Imperialist Women's Movement in Asia and the Women's International Democratic Federation", dalam Signs: Journal of Women in Culture and Society, Vol. 41, No. 2, 2016.
}

para akademisi. Historiografi sejarah diplomasi Indonesia bahkan masih belum memuat peranan para perempuan (Wulandari 2021:4). Karenanya, kaum perempuan menjadi kaum yang termarginalkan dalam catatan sejarah politik luar negeri secara umum, dan sejarah diplomasi secara khusus.

Ketiadaan perempuan dalam historiografi sejarah diplomasi Indonesia secara khusus menimbulkan kesan bahwa diplomasi merupakan ruang maskulin yang hanya dapat digeluti oleh kaum laki-laki. Padahal sejak awal kemerdekaan Indonesia, para perempuan telah terlibat dalam upaya diplomasi ini. Beberapa perempuan Indonesia seperti Maria Ullfah Soebadio dan Supeni Pudjobuntoro pernah diutus sebagai ad hoc diplomat ${ }^{2}$ dalam beberapa misi diplomasi. Tidak lama pasca-kemerdekaan bangsa

2 Ad hoc diplomat merupakan orang yang diutus dalam layanan diplomatik tertentu dan tidak selalu berasal dari Kementerian Luar Negeri 
Indonesia, Maria Ullfah diutus oleh

Sutan Syahrir untuk melakukan misi perlindungan, yakni mencari dan memulangkan para perempuan Indonesia yang dibawa oleh Jepang ke Singapura (Wulandari 2021:68). Sementara itu, Supeni Pudjobuntoro pernah diutus ke dalam beberapa misi strategis negara seperti misi pembebasan Irian Barat hingga mendukung Mesir dalam nasionalisasi Terusan Suez pada tahun 1956. Tidak hanya sebagai diplomat, para perempuan juga terlibat sebagai "duta" dalam berbagai misi diplomasi kebudayaan Indonesia. Mereka yang mahir membatik, menari, atau merupakan public figure memiliki peran penting untuk memperkenalkan kebudayaan Indonesia di luar negeri sejak awal kemerdekaan (Wulandari 2020).

Praktik diplomatik yang sama juga ditunjukkan oleh para istri diplomat Indonesia. Peran para istri diplomat ini sebenarnya sangat penting dalam diplomasi awal kemerdekaan, di mana politik luar negeri Indonesia masih berada dalam proses pembentukan. Praktik diplomatik pada awal kemerdekaan Indonesia ini juga menarik untuk dibahas karena harus memperjuangkan pengakuan internasional atas kemerdekaan Indonesia. Tugas yang diemban tokoh diplomat awal Indonesia seperti Agus Salim, Ahmad Soebardjo, Hatta, Sutan Syahrir, Roeslan Abdulgani, hingga Soebandrio menjadi berlipat ganda karena di samping memperjuangkan pengakuan atas kemerdekaan Indonesia, mereka juga memiliki tanggung jawab untuk membentuk citra Indonesia dalam diplomasi pascakolonial di level global. Bagi para diplomat yang telah menikah, tugas-tugas mereka dalam misi diplomasi juga tidak dapat dilepaskan dari dukungan perempuan yang menjadi pendampingnya.

Dari beberapa perempuan yang berstatus sebagai istri diplomat, Hurustiati Soebandrio - istri diplomat Soebandrio - menjadi salah satu yang menorehkan capaian penting dalam sejarah diplomasi Indonesia. Hurustiati diketahui mendampingi Soebandrio hingga tahun 1960an. Dalam periode panjang ini, Hurustiati menemani Soebandrio dalam berbagai misi, mulai dari memperjuangkan pengakuan kedaulatan, menjalin hubungan diplomatik dengan beberapa negara, hingga menjalankan misi penting negara seperti pembebasan Irian Barat.

Tugas diplomatik pertama Soebandrio adalah untuk menjadi perwakilan Indonesia untuk Kerajaan Inggris pada tahun 1947. Pengirimannya ke Inggris merupakan bagian dari upaya memperoleh pengakuan kedaulatan, bersamaan dengan pembukaan Indonesian Office di beberapa kota besar seperti Singapura, Canberra, Kairo, Washington, hingga New Delhi (Cheong 2003:36). Karenanya, para diplomat yang ditugaskan adalah mereka yang memiliki kapasitas dalam memahami politik luar negeri hingga politik global, sehingga mampu mengemban tugas dengan baik. Pasca penugasannya di Inggris, Soebandrio kemudian dipindahkan ke Moskow untuk mengawal hubungan diplomatik Indonesia dengan Uni Soviet pada tahun 1954. Soebandrio masih menjadi diplomat kepercayaan Soekarno hingga 
Handep Jurnal Sejarah dan Budaya Vol. 5, No. 1, Desember 2021, hlm. 1-26

tahun 1960an. Namun sepanjang masa penugasannya sebagai diplomat, tahun 1947 sampai 1954 atau masa dimana Soebandrio ditugaskan di Inggris menjadi masa yang sangat krusial bagi Republik Indonesia. Pada periode ini, Soebandrio mengemban tugas untuk tidak hanya mengupayakan pengakuan kedaulatan, tetapi juga memperkenalkan Indonesia di level global.

Dalam menjalankan tugas sebagai diplomat, peran Hurustiati sebagai istri Soebandrio tidak dapat dilupakan begitu saja. Hurustiati Soebandrio atau yang kerap disapa $\mathrm{Yu}$ Tien, telah terlibat dalam upaya membentuk citra Indonesia di mata luar negeri yang berbasis di London. Hurustiati terekam turut membentuk citra baik Indonesia sebagai sebuah negara yang berdaulat, merdeka, dan memiliki posisi yang setara dengan negara-negara lainnya. Pembentukan citra ini merupakan salah satu agenda penting Kementerian Luar Negeri pada era revolusi hingga pertengahan 1950an. Adapun tujuan dari membentuk citra Indonesia adalah untuk menunjukkan diri sebagai negara yang layak untuk merdeka, berdaulat, dan memiliki posisi yang setara dengan negara-negara lainnya.

Sayangnya, para akademisi maupun sejarawan hanya menyoroti sosok Hurustiati Soebandrio sebagai figur pergerakan perempuan, atau menyoroti profesinya yang merupakan seorang dokter. ${ }^{3}$ Sementara itu, figur Hurustiati sebagai sosok istri seorang

\footnotetext{
${ }^{3}$ Beberapa akademisi atau sejarawan dan karyanya yang menempatkan Hurustiati dalam konteks ini antara lain: Sylvia A. Chipp dan Justin J. Green, Asian Women in Transition, (Pennsylvania: Pennsylvania
}

diplomat seperti Soebandrio belum mendapat banyak perhatian. Padahal, selama menemani Soebandrio menjalankan tugasnya sebagai diplomat, Hurustiati diketahui sangat gencar berbicara tentang Indonesia di berbagai pertemuan diplomatik hingga acaraacara kebudayaan untuk membentuk citra baik Indonesia. Berdasarkan latar belakang tersebut, kajian ini menganalisa peran Hurustiati Soebandrio dalam membentuk citra Indonesia di Inggris terhitung sejak 1947 sampai 1954.

Konsep utama dalam kajian ini adalah citra (image), yang dapat dimaknai sebagai representasi visual atas orang, benda, kota, atau yang lainnya. Citra negara merupakan sesuatu yang cukup kompleks, yang dapat dibentuk dengan cerita, mitos, fenomena sosial, dan sebagainya. Hal ini mengacu pada pendapat Dinnie (2008:14) di mana citra negara atau yang olehnya disebut sebagai nation brand merupakan hasil visualisasi dari perpaduan berbagai elemen multidimensi dan berbasis kebudayaan, sehingga bangsa atau negara memiliki perbedaan dan keunikan jika dibandingkan dengan

State University, 1980); Susan Blackburn, Women and the State in Modern Indonesia, (Cambridge: Cambridge University Press, 2004); Saskia Eleonora Wieringa, Penghancuran Gerakan Perempuan: Politik Seksual di Indonesia Pascakehancuran PKI, (Yogyakarta: Galang Press, 2010); Cora Vreede-de Stuers, Sejarah Perempuan Indonesia: Gerakan dan Pencapaian, (Depok: Komunitas Bambu, 2017); Mutiah Amini, Sejarah Organsiasi Perempuan Indonesia, (Yogyakarta: Gadjah Mada University Press, 2021). 
yang lainnya. Dalam konteks kajian ini, citra yang dimaksud adalah visualisasi Indonesia sebagai sebuah negara baru, yang berupaya untuk menampilkan dirinya di panggung global. Secara umum, citra negara juga berkaitan erat dalam membentuk reputasi negara di kancah global. Anholt (2013:6) menyatakan bahwa reputasi sebuah negara, sebagaimana pada perusahaan, menunjukkan baik atau tidaknya pengelolaan negara itu sendiri. Selain itu, citra negara juga sangat penting untuk mendapatkan keuntungan yang kompetitif seperti mendapatkan pengakuan kedaulatan, diakui sebagai anggota komunitas global, mendapatkan tempat dalam organisasi regional maupun internasional, dan lain-lain.

Untuk menempatkan kajian ini dalam historiografi yang lebih luas, penting untuk mengetahui sejumlah kajian terdahulu mengenai perempuan dalam ruang lingkup diplomasi. Beberapa studi terdahulu telah menunjukkan sumbangan perempuan dalam politik luar negeri dan diplomasi. Studi ini lebih banyak ditemukan di dalam historiografi Amerika Serikat yang memang telah lebih awal memulai penulisan sejarah secara androgynous. Papachristou (1990) telah mengkaji kehadiran dan peran perempuan dalam kebijakan politik luar negeri Amerika Serikat, khususnya dalam upaya perdamaian di level internasional. Kemudian, Nash (2020) dalam Breaking Protocol: America's First Female Ambassadors, 1933-1964 menguraikan biografi duta besar perempuan di Amerika Serikat. Mengenai peran para istri diplomat dalam menyokong diplomasi Amerika
Serikat, secara rinci telah dikaji oleh Wood (2015) dalam Wives, Clerks, and 'Lady Diplomats': The Gendered Politics of Diplomacy and Representation in the U.S. Foreign Service, 1900-1940. Wood (2015) menguraikan bahwa para istri diplomat ('the lady diplomats') berperan penting dalam menjadi "mitra dinas" diplomat lakilaki karena perempuan dianggap memiliki sifat keibuan, sehingga sangat penting untuk menyokong negosiasi yang dilakukan oleh suaminya sebagai diplomat. Kajian Wood ini menjadi sangat penting untuk memberikan "legitimasi" atas pentingnya peran seorang istri diplomat, sehingga diplomasi tidak lagi dilakukan oleh para pejabat resmi di bawah Kementerian Luar Negeri.

Sementara itu, kehadiran perempuan dalam historiografi Indonesia dapat dikatakan masih sangat terbatas. Dalam Sejarah Diplomasi Republik Indonesia dari Masa ke Masa yang ditulis oleh Panitia Penulisan Sejarah Diplomasi Republik Indonesia dari Departemen Luar Negeri (1996), peran para istri diplomat tidak disinggung. Kajian tersebut hanya fokus kepada peran para diplomat laki-laki dalam menjalankan upaya diplomasi di luar negeri. Begitu pula pada kajian Leifer (1989) yang berjudul Politik Luar Negeri Indonesia. Kajiannya tentang politik luar negeri sebagai kerangka kebijakan pelaksanaan misi diplomasi Indonesia dari masa ke masa ini tidak menampilkan peran para istri diplomat. Karenanya, penulisan sejarah diplomasi Indonesia sejauh ini terkesan sangat maskulin. Namun dewasa ini, mulai ada upaya untuk mengeluarkan 
Handep Jurnal Sejarah dan Budaya Vol. 5, No. 1, Desember 2021, hlm. 1-26

penulisan sejarah diplomasi dari ruang maskulinitas.

Secara khusus dalam historiografi Indonesia, kajian terbaru ditulis oleh Wulandari (2020) dalam Kaum Perempuan dalam Diplomasi Kebudayaan Indonesia 1945-1960an menyoroti peran perempuan dalam membentuk dan memperkenalkan citra baik Indonesia di luar negeri melalui kebudayaan. Kemudian, dalam karya lainnya yakni Di Balik Meja Perundingan: Tiga Diplomat Perempuan dalam Misi Diplomasi Indonesia (1946-1960an) Wulandari (2021) membahas peran tiga diplomat perempuan Indonesia. Ketiga tokoh yang dimaksud yakni Maria Ullfah Soebadio, Supeni Pudjobuntoro, serta Laili Roesad. Meskipun telah ada upaya untuk menampilkan peranan perempuan dalam diplomasi Indonesia, namun peran istri diplomat belum mendapatkan perhatian. Karenanya, berdasarkan tinjauan terhadap beberapa kajian sebelumnya, maka dapat disimpulkan bahwa sejauh ini belum ada kajian yang memposisikan peran Hurustiati Soebandrio dalam membentuk citra Indonesia selama berada di London. Oleh karena itu, kajian ini sekiranya dapat berkontribusi untuk menampilkan peranan istri diplomat dalam penulisan sejarah diplomasi Indonesia dan sejarah perempuan. Dalam ilmu sejarah secara umum, kajian ini juga turut berkontribusi dalam penulisan sejarah yang mewadahi peran perempuan.

Berkaca pada kajian-kajian sebelumnya, peranan istri diplomat seperti Hurustiati Soebandrio ini penting untuk dikaji agar sejarah diplomasi Indonesia dapat dipahami secara lebih utuh. Hal ini mengacu pada hasil kajian Lindsay (dalam Lindsay dan Liem, ed. 2012) dalam Performing Indonesia Abroad. Lindsay berpendapat bahwa upaya diplomasi bukan sematamata bergantung pada diplomat sebagai aktor utamanya, melainkan juga orangorang selain diplomat. Karenanya, Lindsay (2012) yang mengajukan peran diplomatik para seniman di luar negeri ini memberikan penguatan bahwa bukan tidak mungkin jika para istri diplomat, termasuk Hurustiati Soebandrio, adalah salah satu aktor dalam upaya membentuk citra baik Indonesia di Inggris.

Secara umum, kajian ini bertujuan untuk menunjukkan hubungan istri diplomat dengan kepentingan negara di bidang politik luar negeri dan diplomasi. Kemudian secara historiografis, kajian ini diharapkan dapat mendorong penulisan sejarah diplomasi Indonesia yang lebih androgynous.

\section{B. METODE}

Kajian ini dikerjakan menggunakan metode sejarah yang terdiri atas pemilihan topik, heuristik, verifikasi atau kritik sumber, interpretasi, dan penulisan atau historiografi (Kuntowijoyo 2013:69). Tahap Heuristik dilakukan dengan mengumpulkan arsip, surat kabar, dan majalah sebagai sumber primer, sementara buku dan artikel ilmiah menjadi sumber sekunder. Tahap ini dilakukan di beberapa institusi seperti Arsip Nasional Republik Indonesia, Perpustakaan Nasional RI, Perpustakaan UGM, serta Perpustakaan Fakultas Ilmu Budaya UGM. Heuristik 
juga dilakukan melalui media daring yang dapat diakses secara terbuka sebagai alternatif pengumpulan sumber.

Tahap selanjutnya yakni verifikasi atau kritik sumber, dilakukan dengan menganalisa dan membandingkan isi antara satu sumber dengan sumber lainnya. Kritik sumber yang dilakukan terutama berupa koroborasi data, seperti jika ditemukan perbedaan mengenai tahun keberangkatan Soebandrio ke Inggris. Karenanya, beberapa sumber sekaligus harus dibandingkan dan diperoleh fakta bahwa Soebandrio telah berangkat ke Inggris sejak tahun 1947, meskipun statusnya sebagai duta besar baru diberikan pada 1950. Dari tahap verifikasi, sumber-sumber yang kredibel kemudian diinterpretasi, sehingga menghasilkan fakta-fakta sejarah. Fakta inilah yang kemudian disusun untuk menjadi sebuah historiografi yang utuh dan kronologis.

\section{HASIL DAN BAHASAN}

Sepanjang menemani Soebandrio bertugas sebagai diplomat, Hurustiati menorehkan beberapa peranan pentingnya. Namun, peranan tersebut tidak dapat dilepaskan dari pengalaman hidup Hurustiati Soebandrio sebelumnya. Akan tetapi, selama harus menjalankan tugasnya menemani Soebandrio di luar negeri, Hurustiati juga harus berperan ganda yakni sebagai ibu sekaligus sebagai istri seorang diplomat. Karenanya, ada pergolakan batin yang sempat terjadi pada diri Hurustiati, meskipun pada akhirnya ia tetap mampu menjalankan perannya sebagai istri diplomat sekaligus turut membentuk citra baik Indonesia di luar negeri.
1. Mengenal Hurustiati Soebandrio Hurustiati Soebandrio merupakan tokoh kelahiran Lawang, Jawa Timur pada 19 Juli 1917 (Jones 1971:438). Sayangnya, tidak banyak catatan mengenai detail riwayat hidup Hurustiati. Hanya saja, dapat dipastikan bahwa Hurustiati berasal dari kalangan yang cukup berada, mengingat ia pernah menempuh pendidikan di ELS (Europeesche Lagere School). Setelah lulus dari pendidikan dasar pada tahun 1931 Hurustiati kemudian didaftarkan di HBS (Hoogere Burgere School) Malang, sebuah sekolah menengah dengan masa pendidikan lima tahun. Sebagaimana sekolah-sekolah Eropa lainnya, HBS Malang juga didominasi oleh anak-anak dari bangsa Eropa, terutama lulusan dari ELS. Kemudian ketika menempuh pendidikan tinggi, Hurustiati memilih sekolah tinggi kedokteran atau Geneeskundige Hooge School (GHS) di Jakarta (Batavia) pada tahun 1937 (Het nieuws van den dag voor Nederlandsch-Indie 25 Agustus 1937). Geneeskundige Hooge School Batavia ini merupakan kelanjutan dari School tot Opleiding van Indische Artsen (STOVIA), yang didirikan pada tahun 1927 (Dhita, 2020:192). Staf pengajar di sekolah ini pun banyak yang merupakan alumnus dari STOVIA. Sebagai lulusan dari GHS Batavia, tentu Hurustiati Soebandrio lebih dikenal sebagai seorang dokter.

Pada tahun 1940, Hurustiati menikah dengan Soebandrio. Setelah menikah dengan Soebandrio, Hurustiati lebih dikenal sebagai Nyonya Soebandrio. Dari pernikahan mereka, lahir seorang anak laki-laki yang bernama Budoyo (Moritz, ed. 1963:408). 
Handep Jurnal Sejarah dan Budaya Vol. 5, No. 1, Desember 2021, hlm. 1-26

Dalam kehidupan sehari-harinya di rumah, Hurustiati dan keluarganya sering menggunakan Bahasa Belanda sebagai media komunikasi. Tentu, penggunaan Bahasa Belanda tersebut menjadi wajar mengingat baik Hurustiati maupun Soebandrio merupakan kalangan terdidik yang dapat dengan mudah mempelajari Bahasa Belanda, bahkan bergaul dengan orang-orang Belanda.

Hurustiati Soebandrio, sebagaimana dikemukakan oleh Vreedede Stuers (2017) juga merupakan tokoh yang aktif dalam pergerakan perempuan, sebab ia merupakan anggota Kowani (Kongres Wanita Indonesia). Kemudian sebagai tokoh pergerakan perempuan, Hurustiati Soebandrio juga memiliki pandangan yang sangat reformis tentang kesetaraan gender, terutama keyakinan bahwa kaum perempuan dapat terjun ke ranah publik. Pandangannya tentang emansipasi perempuan banyak dipengaruhi oleh Raden Ajeng Kartini. Karakter dan pandangannya mengenai kesetaraan gender ini dapat diketahui melalui pidatonya mengenai Hari Kartini yang diucapkan melalui Radio BBC London pada 21 April 1951 (Anonim Juni 1951:10).

Kemudian pada awal kemerdekaan Indonesia, Hurustiati bekerja sebagai seorang dokter (Algemeen Dagblad 4 April 1964). Meskipun pekerjaan tersebut hanya dijalani selama dua tahun, tetapi hal itu menjadi pengalaman yang sangat membekas bagi Hurustiati Soebandrio. Pasalnya, pekerjaannya sebagai dokter menuntutnya untuk terjun langsung ke dalam derap revolusi Indonesia. Kiprahnya sebagai dokter sekaligus tokoh pergerakan perempuan membuat sosok Hurustiati menjadi tokoh yang mudah beradaptasi dan terbuka terhadap berbagai perubahan. Dengan demikian, Hurustiati mampu menempatkan dirinya sesuai dengan lingkungan dan orang-orang yang sedang berinteraksi dengannya. Misalnya saja, Rosihan Anwar (2009:224-225) pernah menceritakan keberanian Hurustiati berdansa secara apik dengan Andrey Gromyko, seorang diplomat Uni Soviet, dalam resepsi diplomatik. Karakternya yang adaptif dan terbuka ini kelak sangat membantunya ketika ia menemani Soebandrio bertugas di London. Selama masa revolusi pula, Hurustiati tetap menjadi tokoh yang tampil ke panggung global untuk mewakili Kowani. Hal ini ditujukan agar perempuan internasional mau mengulurkan bantuan dan dukungan untuk Indonesia yang pada saat itu terus menerus diserang oleh Belanda. Pada 1946 misalnya, Hurustiati bersama dengan Nyonya Soetiah dan Nyonya Hamdani mewakili Kowani untuk menggalang dukungan terhadap Indonesia di New Delhi, India (Ningrum dan Niwandhono 2013:87).

Setelah dua tahun menjalani tugasnya sebagai dokter, Hurustiati kemudian harus menemani Soebandrio ke London, Inggris pada tahun 1947. Sebelumnya, Soebandrio merupakan Sekretaris Jenderal di Departemen Penerangan. Namun secara bertahap, Soebandrio memiliki kedekatan dengan Presiden Soekarno dan Syahrir. ${ }^{4}$

4 Pada awalnya, Soebandrio merupakan loyalis Syahrir dalam Partai Sosialis Indonesia (PSI). Namun setelah pengangkatannya sebagai utusan Indonesia di London, kedekatannya 
Karenanya, ia ditugaskan sebagai perwakilan Indonesia untuk mendirikan Indonesian Information Office (atau Indonesian Office), sebuah kantor perwakilan yang menjadi cikal bakal Kedutaan Besar Republik Indonesia. Mengenai penugasannya ini Soebandrio (2001:58) menulis bahwa "penunjukan itu tiba-tiba saja. Tidak melalui proses, misalnya, menjadi pegawai negeri dulu. Mungkin karena saat itu jumlah manusia tidak sebanyak sekarang. Dan, penunjukan Presiden Soekarno langsung saya terima. Istri saya juga setuju."

Penugasan Soebandrio ke London menuntut Hurustiati sebagai seorang istri untuk menemaninya. Karenanya, status dan peran Hurustiati tidak lagi hanya sebagai istri dan ibu, melainkan juga menjadi seorang istri diplomat ("lady diplomat").

Namun selama berada di London, Hurustiati Soebandrio tidak hanya menjalankan tugas sebagai seorang istri dan pendamping diplomat. Hurustiati memilih untuk melanjutkan studi ke London School of Economics and Political Science. Di kampus tersebut, ia memilih Antropologi sebagai bidang kajiannya. Hurustiati berhasil meraih gelar doktor dengan disertasinya yang berjudul Javanese Peasant Life

dengan Syahrir menurun dan ia berbalik dengan mendekati Soekarno. Renggangnya hubungan Soebandrio dan Syahrir ini terlihat ketika PSI pecah pada tahun 1948, dimana Soebandrio memilih untuk tidak lagi berurusan dengan PSI. Lebih lengkap dapat dilihat di: Rosihan Anwar, Sutan Syahrir: Negarawan Humanis, Demokrat Sejati yang Mendahului Zaman, (Jakarta: Kompas, 2011), hlm. 137-138.
(Quiko April-Juni 1972:50). Selain itu, Hurustiati Soebandrio juga aktif menulis. Sosoknya yang sangat mengagumi Kartini bahkan membawanya untuk menulis biografi Kartini yang hingga tahun 1953 telah dicetak ulang sebanyak empat kali (De Nieuwsgier 22 Januari 1953).

Meskipun sibuk menulis bahkan terkadang mengunjungi mahasiswa di universitas di Inggris, Hurustiati tetap berupaya menjalani tugasnya sebagai istri seorang diplomat. Ia rutin menemani Soebandrio ke dalam pertemuan-pertemuan penting dengan para diplomat dari negara-negara lain. Kemudian dalam resepsi diplomatik, Hurustiati juga terbiasa menemani Soebandrio. Selama menemani Soebandrio di London, Hurustiati dikenal sebagai sosok perempuan yang cerdas dan sangat peduli terhadap citra Indonesia di luar negeri. Hal ini juga didorong oleh situasi pada saat itu di mana Indonesia memang sangat memerlukan dukungan dan pandangan yang baik dari masyarakat internasional.

Selama masa revolusi, Belanda berupaya menggempur pertahanan militer Indonesia. Tak hanya itu, Belanda juga memberlakukan blokade laut di Sumatra dan Jawa yang memperburuk kondisi perekonomian nasional. Padahal, republik pada saat yang sama tengah membutuhkan dana, yang "...bukan hanya untuk biaya militer tetapi termasuk biaya untuk menjalankan pemerintahan dan diplomasi" (Pranoto 2001:172). Karenanya selama revolusi, kepedulian masyarakat internasional sangat diperlukan. Kemudian pasca 1950 , Indonesia memerlukan perhatian 
Handep Jurnal Sejarah dan Budaya Vol. 5, No. 1, Desember 2021, hlm. 1-26

masyarakat internasional untuk membentuk citranya sebagai negara yang bukan hanya merdeka, tetapi juga kaya, multukultur, unik, dan indikasi modernitas lainnya. Citra ini juga sangat berguna untuk membantu memperjuangkan kepentingan Indonesia yang belum final, seperti pembebasan Irian Barat.

Setelah menemani Soebandrio menjadi Duta Besar di London, Hurustiati kemudian mendampingi Soebandrio dalam menjalankan tugastugas selanjutnya. Ia juga terus aktif dalam kiprah pergerakan perempuan nasional. Aktivitasnya dalam gerakan perempuan seperti memimpin KOWANI, mendorong kemampuan dan keterampilan perempuan Indonesia, dan lain-lain membuat Hurustiati hadir seakan-akan sebagai ikon para perempuan Indonesia. Dalam momen bersejarah perempuan Asia Afrika, yakni Konferensi Wanita Asia Afrika di Kolombo pada tahun 1958, Hurustiati Soebandrio juga turut serta. Keputusan melibatkan Hurustiati dalam konferensi akbar ini merupakan hasil dari Kongres Kowani yang diselenggarakan di Palembang pada tahun 1955 (Amini 2021:90).

Pada tahun-tahun selanjutnya, Hurustiati Soebandrio semakin mendominasi gerakan perempuan di kancah nasional. Dominasi ini terwujud melalui posisinya sebagai Ketua KOWANI. Dengan posisinya ini, Hurustiati memiliki kendali atas organisasi perempuan di Indonesia. Dominasinya juga didorong oleh kedekatannya dengan Pemerintah pada saat yang sama, dimana ia merupakan loyalis Soekarno. Chipp dan Green (1980:167) misalnya mengemukakan bahwa tokohtokoh lain seperti Utami Suryadarma juga sangat menonjol di kancah nasional, namun ia dibayang-bayangi oleh dominasi Hurustiati Soebandrio. Sejarah gerakan perempuan terutama pada masa demokrasi terpimpin, bahkan dinilai sebagai cerita yang didominasi oleh sosok Hurustiati Soebandrio (Chipp dan Green 1980:167). Dominasinya dalam hal ini, tidak jarang memberikan kesan pada para anggota KOWANI bahwa peran mereka dibayang-bayangi oleh Hurustiati. Terlepas dari perdebatan ini, Hurustiati Soebandrio memang memberikan sumbangan bagi diplomasi Indonesia hingga tahun 1960an. Misalnya, Hurustiati bersama dengan Maria Ulfah dan tokoh-tokoh lainya pernah memperjuangkan Irian Barat melalui Konferensi Wanita Asia Afrika pada tahun 1958 (Radjasa 14 Februari 1958:3).

Hurustiati juga aktif dalam mengurus kesehatan masyarakat, seperti memulai perencanaan program Keluarga Berencana di Jakarta (Departemen Kesehatan RI, 1980:40). Sayangnya, karir Hurustiati meredup pascaperistiwa G30S/1965, dimana Soebandrio diduga terlibat dalam gerakan tersebut. Soebandrio ditetapkan menjadi tahanan politik oleh pemerintahan Soeharto. Hurustiati yang juga dinilai sebagai tokoh berhaluan kiri pun turut terkena dampaknya. ${ }^{5}$ Kondisi

\footnotetext{
5 Menurut Saskia Eleonora Wieringa, Hurustiati Soebandrio merupakan tokoh berhaluan kiri dan dinamis, termasuk dalam memimpin organisasi maupun gerakan perempuan. Lihat di buku karya Saskia Eleonora Wieringa, Penghancuran Gerakan
} 
ini membuat kehidupan Hurustiati Soebandrio sangat berubah, menanggung beban mental sebagai orang yang diduga terlibat dalam rentetan peristiwa G30S/1965. Terkait hal ini, Soebandrio juga menuturkan dalam keasaksiannya, bahwa:

...di dalam penjara, saya sama sekali tidak disiksa secara fisik. Kalau disiksa mental, sudah jelas. Interogasi tak habis-habisnya hanya untuk tujuan menjatuhkan mental. Sebagai mantan pejabat tinggi negara, saat itu mental saya sudah jatuh. Dari pemegang kekuasaan negara berubah menjadi orang tahanan. Mungkin saya mengalami depresi. Istri saya tentu mengalami hal yang sama. Anak saya satu-satunya masih kecil (2001:64).

Menurut Soebandrio, selama ia dipenjara, Hurustiati hanya memiliki anak satu-satunya Budoyo yang menjadi penghiburnya. Namun, menuju pertengahan 1970an, Budoyo meninggal dunia dan peristiwa ini membuat Hurustiati depresi berat. “...Budojo meninggal dunia karena serangan jantung. Ibunya benar-benar mengalami depresi berat. Saya bisa membayangkan, betapa isteri saya hidup nelangsa", tutur Soebandrio (2001:65). Tak lama kemudian dan setelah hampir satu dekade menyandang status sebagai istri terdakwa G30S/1965, Hurustiati menghembuskan napas terakhirnya di Rumah Sakit Cikini Jakarta pada

Perempuan: Politik Seksual di Indonesia Pascakehancuran PKI, (Yogyakarta: Galang Press, 2010), hlm. 201.
15 April 1974 (De Volkskrant 16 April 1974).

\section{Hurustiati Soebandrio dalam} Membentuk Citra Indonesia di Inggris

Meskipun Hurustiati merupakan tokoh yang adaptif, terbuka, dan terbiasa mengemban tugas negara di luar negeri, bukan tidak mungkin jika di dalam benaknya juga terjadi pergolakan yang cukup berat. Pergolakan ini bisa dilihat dalam tulisan Sujud (Juli 1954:358) yang memperlihatkan Hurustiati Soebandrio dalam dua sisi. Di satu sisi, Hurustiati merupakan perempuan yang memperlihatkan ketangguhan dan kemandiriannya. Namun di sisi lain, ia menunjukkan kekhawatiran mengenai peran gandanya sebagai seorang ibu. Dalam artikelnya, Sujud (Juli 1954:358) meriwayatkan bahwa, bahwa Hurustiati bukan hanya berstatus sebagai istri seorang Soebandrio, melainkan juga menjadi seorang ibu dari anak tunggalnya, Budoyo. Selama berada di London, Hurustiati juga harus memikirkan kehidupan dan pendidikan anaknya yang menurutnya tidak boleh kehilangan identitasnya sebagai orang Indonesia. Karenanya, Hurustiati juga harus berperan ganda, yakni sebagai istri dan ibu. Bahkan ketika harus menemani Soebandrio ke Inggris, perannya pun menjadi bertambah, yakni harus menjadi istri dari seorang diplomat terlebih seorang duta besar.

Memutuskan untuk menemani Soebandrio dalam penugasannya di London, Inggris, mengharuskan Hurustiati meninggalkan sanak keluarganya di Indonesia. Tentu, hal ini menjadi tantangan bagi Hurustiati 
Soebandrio. Meskipun demikian, Hurustiati Soebandrio tetap berupaya untuk menemani Soebandrio dengan sebaik-baiknya. Sebagai tokoh perempuan yang sadar akan kesetaraan gender, Hurustiati menyadari bahwa ia tetap dapat berperan sebagai istri seorang diplomat. Hurustiati kemudian percaya pada dirinya sendiri bahwa ia memiliki kemampuan untuk menjalankan tugas tersebut meskipun jauh dari keluarga besarnya. Bagaimanapun, gagasan feminisme yang meluas pada abad ke-20, telah mendorong kaum perempuan (termasuk Hurustiati) untuk dapat mengelola urusan pribadi dengan urusan publik seorang diri (Vreede-de Stuers 2017:253). Selama menemani Soebandrio di London, Hurustiati dikenal sebagai istri diplomat yang sangat berpengaruh dalam membentuk citra baik Indonesia di Inggris secara khusus, dan di Eropa secara umum. Bahkan, beberapa majalah tahun 1950an seperti Majalah Wanita mengakui bahwa Hurustiati Soebandrio merupakan perempuan yang sangat gencar memperkenalkan Indonesia ke dunia luar melalui penuturan dan ceramah-ceramahnya (Anonim April 1954:167).

Pada dasarnya, apa yang dilakukan Hurustiati untuk membentuk citra baik Indonesia adalah sesuatu yang wajar dilakukan oleh istri seorang diplomat. Sebagaimana telah disebutkan pada bagian awal kajian ini, bahwa seorang istri diplomat adalah mitra dinas bagi suaminya. Lalu, kapan Hurustiati mulai melakukan upaya tersebut? Jika mengacu pada pengangkatan Soebandrio sebagai Duta Besar di London, maka Hurustiati mulai melakukan upaya diplomasi non-formal tersebut sejak 1950. Hal ini sesuai dengan Surat Keputusan Presiden No. 87 tahun 1950 yang menyatakan bahwa Dr. Soebandrio resmi menjadi Duta Besar Republik Indonesia Serikat (RIS) untuk London, Inggris (Inventaris Arsip Sekretariat Negara Seri Produk Hukum 1949-2005 No. 4638). Akan tetapi, Hurustiati telah memulai "misi" tersebut jauh sebelum Surat Keputusan pengangkatan duta besar diterbitkan. Berdasarkan sumber-sumber yang telah dikaji, ditemukan fakta bahwa Hurustiati Soebandrio telah mulai membentuk dan memperkenalkan citra Indonesia di luar negeri sejak tahun 1947. Tahun 1947 tersebut bersamaan dengan penugasan Soebandrio untuk mendirikan Indonesian Information Office di London, Inggris. Indonesian Information Office merupakan kantor perwakilan Indonesia di luar negeri, yang berfungsi sebagaimana kantor kedutaan pada umumnya. Selain berada di London, Indonesian Information Office juga didirikan di beberapa tempat seperti New York (Amerika Serikat), Singapura, dan beberapa negara lainnya. Kantor tersebut didirikan dengan tujuan menampilkan wajah Indonesia sebagai sebuah negara yang merdeka, serta mengupayakan bantuan material dan finansial untuk perjuangan bangsa Indonesia (Cheong 2003:36). Selain itu, Indonesian Information Office juga mengupayakan pengakuan internasional atas kedaulatan Indonesia. Karenanya, tugas Soebandrio pun juga tidak jauh-jauh dari upaya mencari pengakuan kedaulatan atas kemerdekaan Republik Indonesia. Selain itu, Soebandrio 
juga harus menunjukkan citra baik Indonesia di kancah internasional, terutama di Eropa.

Dalam mendukung upaya Soebandrio untuk memperjuangkan pengakuan kedaulatan hingga menunjukkan citra Indonesia, Hurustiati sebagai istrinya memainkan peranan yang sangat penting. Bagaimanapun, harus disadari bahwa hampir dalam setiap acara diplomatik yang didatangi Soebandrio, Hurustiati selalu turut serta. Begitu pula selama berada di London, Hurustiati atau yang sering dipanggil Yu Tien, selalu menemani Soebandrio dalam berbagai kegiatan dinasnya. Bahkan, “... dimana ada Mas Bandrio, disitu ada Yu Tien" (Anonim April 1954:167). Karenanya, Hurustiati juga "dituntut" untuk mampu memperkenalkan citra baik Indonesia.

Masa perjuangan diplomasi dan pembentukan citra Indonesia oleh Hurustiati sekiranya dapat dibagi menjadi dua periode. Pada tahun 19471950, pembentukan citra ini lebih ditujukan untuk mempertahankan kedaulatan Indonesia. Periode ini menjadi sangat krusial dalam diplomasi Indonesia di Inggris, karena periode ini menentukan masa depan Indonesia sebagai sebuah negara yang berdaulat dan memiliki tempat di perpolitikan internasional. Kemudian pasca-1950, pembentukan citra mulai meluas melalui ranah kebudayaan, kuliner, dan sebagainya.

Mengenai upaya yang dilakukan oleh Hurustiati selama periode panjang ini agaknya lebih tepat untuk disebut sebagai "pembentukan" (forming) citra Indonesia, bukan sebagai sebuah upaya untuk "memperkenalkan" atau "menampilkan" (performing). Hal ini dikarenakan dalam kurun waktu 1947 hingga masa akhir penugasan Soebandrio sebagai Duta Besar di London, Pemerintah Indonesia belum banyak mengirimkan misi diplomasi yang secara khusus ditujukan dalam rangka memperkenalkan citra Indonesia. Karenanya, Hurustiati Soebandrio harus terlebih dulu meramu atau membentuk (forming) citra baik Indonesia. Era menampilkan (performing) citra Indonesia kiranya lebih tepat ditujukan pada pasca-1954, mengingat Pemerintah Indonesia memang baru secara resmi mengirimkan misi-misi kebudayaan ataupun misi serupa lainnya untuk memperkenalkan citra baik Indonesia secara lebih luas (Lindsay dalam Lindsay dan Liem 2012). Sebenarnya, upaya untuk membentuk citra Indonesia di luar negeri bukan hanya dilakukan oleh Hurustiati Soebandrio, melainkan juga oleh pejabat-pejabat diplomatik di kantor kedutaan lainnya. Misalnya di Indonesian Information Office di New York, Amerika Serikat, tokoh-tokoh Indonesia juga turut membentuk citra Indonesia dengan melakukan diplomasi kebudayaan (Wulandari 2020:328).

Kembali pada peranan Hurustiati, maka segera setelah penugasan Soebandrio sebagai diplomat, Hurustiati berupaya untuk membentuk citra Indonesia dengan sebaik-baiknya. Selama 1947-1950, Hurustiati membantu Soebandrio untuk mendekati Pemerintah Inggris untuk mendukung upaya pengakuan kedaulatan masyarakat internasional atas Indonesia. Pada periode pertama ini, Soebandrio sebagai perwakilan Indonesia ber- 
upaya melakukan negosiasi dengan Pemerintah Inggris agar terus mendukung perjuangan bangsa Indonesia. Upaya ini cukup masuk akal untuk dilakukan, mengingat pemerintahan Inggris di London memilih untuk prorepublik (Cheong 2003:36). Tak hanya itu, perwakilan Inggris di Singapura pun cenderung pro-republik meskipun Inggris sendiri merupakan bagian dari Sekutu. Soebandrio juga melakukan pendekatan terhadap Buckingham Palace agar Inggris tetap mendukung Indonesia. Kemudian pada tahun 1950, Soebandrio mengupayakan kerja sama ekonomi dengan tujuan menstabilkan perekonomian Indonesia pasca-perang. Kerja sama ini dibahas dengan Sekretaris Kementerian Luar Negeri Inggris, Ernest Bevin (Indian Daily Mail 22 Maret 1950:3).

Sejak tahun 1947, selama menemani Soebandrio bertugas di London, Hurustiati memberikan ceramah atau penjelasan kepada masyarakat di Inggris dan sekitarnya setiap ada kesempatan atau acara-acara diplomatik, “... sehingga Indonesia tidak saja dikenal sebagai negara yang merdeka, tetapi juga dikenal karena ketinggian kebudayaannya, adat istiadatnya, keseniannya" (Anonim 1954:167). Dalam acara makan malam ataupun pertemuan Soebandrio dengan petinggi negara lainnya, Hurustiati harus mampu menyampaikan informasi yang baik tentang Indonesia. Hal ini misalnya dilakukan oleh Hurustiati ketika mengunjungi Buckingham Palace (Malaya Tribune 27 Mei 1950:1). Dalam kesempatan ini, Hurustiati menjelaskan Indonesia sebagai negara yang kaya akan kebudayaan dan berdaulat. Bagaimanapun, istri pejabat diplomatik memang menjadi salah satu agen pertukaran informasi antarnegara, terutama untuk menumbuhkan citra baik dan hubungan diplomatik antarnegara yang harmonis (Wood 2015:2). Dengan demikian, meskipun Hurustiati tidak memiliki posisi formal dalam diplomasi yang dilakukan Soebandrio, perannya sebagai pendukung menjadi sangat penting.

Kemudian pasca-1950, dimana kondisi Indonesia sudah jauh lebih stabil secara politik dan pada saat yang sama Belanda juga telah memberikan pengakuan kedaulatan arah diplomasi Indonesia mengalami pergeseran. Diplomasi yang sebelumnya ditujukan untuk mempertahankan dan mencari pengakuan atas kedaulatan, kemudian bergeser menjadi diplomasi dalam rangka mempromosikan Indonesia. Karenanya, perlu upaya awal untuk membentuk citra Indonesia di kancah internasional. Namun, pertanyaan selanjutnya yang muncul adalah citra Indonesia yang bagaimana yang dibentuk oleh Hurustiati Soebandrio? Jawaban atas pertanyaan ini menjadi cukup kompleks. Citra suatu negara apalagi sebuah negara bangsa (nationstate) yang baru merdeka tentu tidak cukup jika hanya digambarkan dengan satu ciri saja. Namun rupanya, citra Indonesia sebagai negara yang kaya akan kebudayaan dan multikultural menjadi konsentrasi pertama dari Hurustiati Soebandrio.

Dalam memulai upaya pembentukan citra Indonesia sebagai negara yang multikultural, Hurustiati Soebandrio memulainya dari hal-hal 
yang kecil. Hampir dalam setiap acara resmi di Inggris, Hurustiati mengenakan kain dan kebaya khas Indonesia sebagai pakaiannya. Selain itu, rambutnya juga disanggul sebagaimana potret perempuan Indonesia ketika mengenakan kebaya. Hal tersebut bahkan dapat dikatakan menjadi identitas Hurustiati selama di London. Bahkan ketika ia bersama Soebandrio mendapatkan undangan ke Istana Buckingham, kain tradisional dan kebaya juga tetap melekat di tubuhnya. Dalam memenuhi undangan Buckingham pada Maret 1951 misalnya, Hurustiati juga tampak mengenakan kebaya dan kain tradisionalnya (The Singapore Free Press 22 Maret 1951:3).

Kemudian, untuk memudahkan pembentukan citra Indonesia sebagai negara yang kaya akan kebudayaan maka Hurustiati secara sukarela menjadi penasehat bagi kedutaan Indonesia di London dalam hal pengenalan kebudayaan. Dalam hal ini, Hurustiati turut mengelola dan mengatur kebudayaan seperti apa yang akan ditampilkan di Inggris. Ia bekerjasama dengan Ny. Budiardjo (pengelola bagian kebudayaan Indonesia di Inggris) dan Ganis Harsono yang merupakan atase pers Indonesia. Sayangnya, sejauh ini belum ditemukan data yang mencatat secara detail kelompok-kelompok kesenian yang pernah tampil di Inggris. Namun, tidak jarang kesenian ini ditampilkan oleh komunitas Indonesia yang memang tinggal di Inggris. Salah satunya ialah acara semacam pekan kebudayaan, di mana terdapat suatu pertunjukan mengenai budaya lokal Indonesia yang ditampilkan oleh kaum ibu, para pelajar, dan pekerja perempuan Indonesia yang ada di Inggris. Hal ini dibenarkan oleh Husrustiati Soebandrio dalam pidatonya pada peringatan Hari Kartini tahun 1951, dimana ia dengan tegas menyatakan bahwa:

...tidak usah panjang lebar saya menceritakan usaha para wanita Indonesia di London. Hanya untuk memberi pesan sekedar, bahwa disini mereka sibuk, kesatu memberi tenaganya kepada keluarga, kedua menuntut pelajaran dan ilmu, ketiga bekerja di Kedutaan Besar, dan semua golongan di sampingnya itu menuntut bermacam-macam pelajaran dan memberi penerangan di luar negeri tentang Indonesia dan kebudayaannya (Anonim 1951:10).

Selain itu, Hurustiati terkadang juga mendatangkan misi kebudayaan yang berangkat langsung dari Jakarta. Misalnya, pada tahun 1952, Hurustiati dan suaminya menginisiasi pementasan kebudayaan Bali mengingat pada saat yang sama, terdapat kelompok penari Bali yang dikirim oleh Indonesia ke Amerika Serikat (Star Weekly 20 September 1952:14). Dari Amerika Serikat, mereka melawat ke London selama dua minggu. Hurustiati dan Soebandrio sengaja memperkenalkan kebudayaan Bali tersebut kepada masyarakat Inggris dan para pejabat diplomatik. Hurustiati sebagai "ibu" bagi komunitas Indonesia di Inggris juga menunjukkan keramahannya pada para penari tersebut. Ia bahkan terkadang ikut menemani mereka menikmati santapan kuliner pada sore hari di Winter Garden Theatre (Star Weekly 20 September 1952:15). 
Tampaknya, selain ingin menunjukkan citra Indonesia sebagai negara yang kaya akan budaya, sebagai perempuan yang berstatus sebagai istri seorang diplomat sekaligus Duta Besar, Hurustiati Soebandrio juga ingin membentuk citra kaum perempuan Indonesia di mata dunia. Hal ini terbukti dari sosoknya yang dengan gencar memperkenalkan tokoh Kartini sebagai bukti bahwa kaum perempuan Indonesia telah lama memiliki gagasan kesetaraan gender. Pandangan Hurustiati tersebut tentu juga dipengaruhi oleh latar belakangnya yang tidak lain merupakan tokoh pergerakan perempuan.

Untuk menunjukkan kepada bangsa-bangsa Eropa, terutama Inggris, bahwa kaum perempuan Indonesia telah cukup lama mengakui kesetaraan gender, Hurustiati memanfaatkan momen Hari Kartini. Setiap tiba pada Hari Kartini yang diperingati pada 21 April, Hurustiati Soebandrio rutin mengadakan acara peringatan di Inggris. Bahkan, tidak jarang ia memberikan pidato mengenai kerja keras kaum perempuan Indonesia yang telah turut serta dalam pergerakan meraih kemerdekaan hingga upaya mempertahankan kemerdekaan. Selain itu, Hurustiati juga mendekati komunitas-komunitas tertentu untuk berbicara tentang kemajuan kaum perempuan Indonesia. Salah satu komunitas yang cukup sering didekati oleh Hurustiati ialah komunitas muslim di London. Bahkan, Hurustiati pernah memberikan ceramah mengenai emansipasi perempuan Indonesia di hadapan komunitas muslim di Islamic Cultural Centre, London pada tahun
1952 (Indian Daily Mail 27 Januari 1952:3). Di Islamic Cultural Centre itu pula, Hurustiati Soebandrio juga pernah memberikan ceramah dengan tema yang sama di hadapan para pejabat diplomatik dan istrinya. Salah satu tokoh yang pernah mendengarkan ceramahnya adalah Begum Rahmitoola, istri dari pejabat diplomatik Pakistan di Inggris (The Chronicle 12 Juni 1952:28).

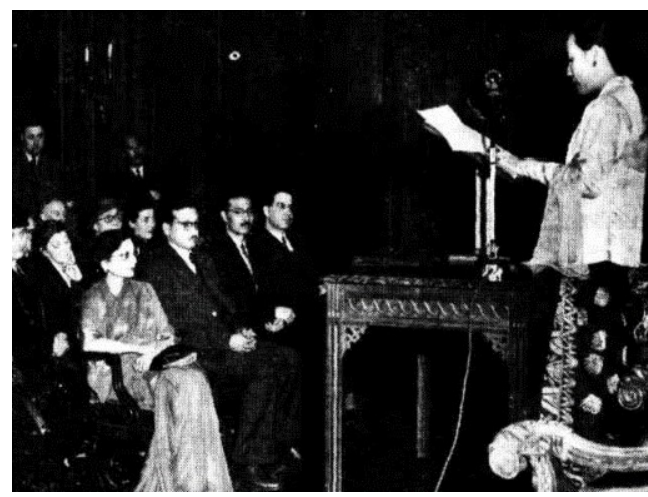

Gambar 1. Hurustiati Soebandrio ketika memberikan ceramah mengenai emansipasi perempuan Indonesia di hadapan pejabat diplomatik di Islamic Cultural Centre, London. Sumber: https://trovele.nla.gov.au/ newspaper.

Kembali pada upaya Hurustiati Soebandrio dalam membentuk citra Indonesia sebagai negara yang kaya akan kebudayaan, maka Hurustiati menginisiasi berbagai acara kebudayaan, baik di dalam lingkungan kedutaan maupun di luar daripada itu. Tidak lama setelah peringatan Hari Kartini pada 1952, tepatnya pada penghujung bulan April, Hurustiati menginisiasi pementasan kebudayaan Indonesia di dalam kantor kedutaan yang terletak di Grosvenor Square, London. Acara tersebut diadakan bersamaan dengan peresmian kantor kedutaan Indonesia pasca renovasi dan 
dekorasi ulang. Dalam kesempatan tersebut, Hurustiati dengan dibantu komunitas Indonesia di Inggris, memperkenalkan kebudayaan mulai dari gamelan hingga mengadakan diskusi terbuka dengan para tamu undangan untuk membicarakan berbagai jenis kebudayaan Indonesia. Bahkan, upaya Hurustiati berhasil menarik perhatian dari tamu undangan. Karenanya, beberapa tamu seperti Johanna Beun dan Karel Noordhoff tertarik untuk bergabung dalam kelompok musik gamelan.

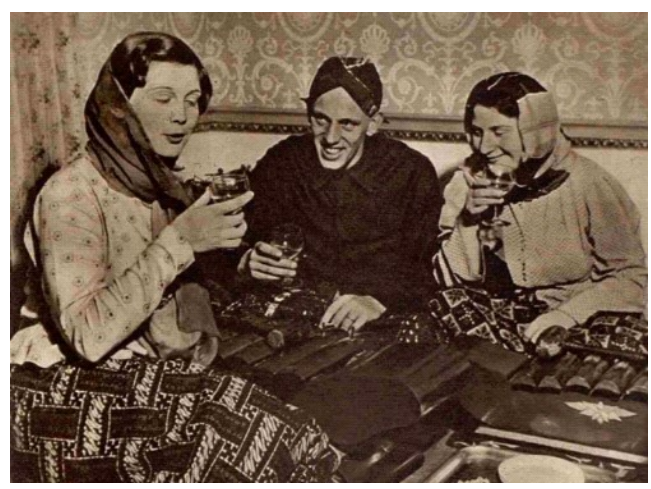

Gambar 2. Permainan Gamelan dalam pementasan yang diadakan oleh Hurustiati Soebandrio. Sumber: https:// www.britishnewspaperarchive.co.uk/.

Sementara itu, beberapa tamu lainnya tertarik untuk mendiskusikan tentang tarian dari Bali. Pada dasarnya, keberhasilan upaya Hurustiati untuk menyadarkan orang-orang Eropa terutama, mengenai kekayaan Indonesia akan kebudayaan, juga tidak lepas dari sikap hangat yang ditunjukkan olehnya kepada para petinggi dari negara lainnya. Bahkan, The Tatler (30 April 1952:29) menyatakan bahwa pesta tersebut merupakan sebuah acara yang sangat hangat, melalui peranan Hurustiati Soebandrio.

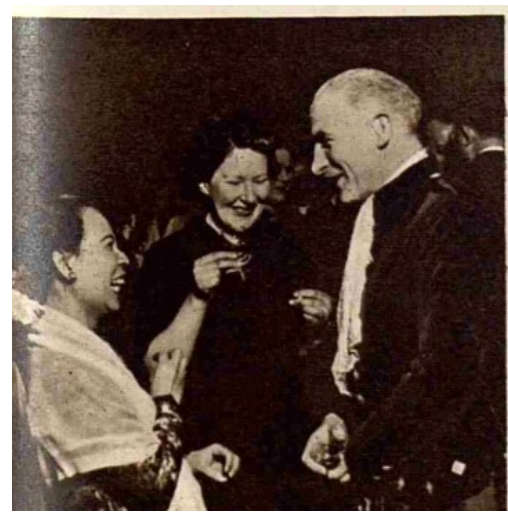

Gambar 3. Hurustiati Soebandrio sedang beramah tamah dengan tamu undangan dalam acara pementasan kebudayaan. Sumber: https://www.britishnewspaperarchive.co.uk/.

Kemudian, pada Juli 1953 Hurustiati Soebandrio mengadakan Malam Kesenian Indonesia. Acara tersebut lebih tepatnya diselenggarakan pada Selasa malam, 23 Juli 1953 (Anonim 1953:62). Dalam acara tersebut, Hurustiati turut mengundang petinggi negara lainnya seperti pejabat Kementrian Luar Negeri Inggris, Duta Besar Arab Saudi, Suriah, Finlandia, Mesir, hingga Duta Besar Lebanon. Sementara itu, beberapa kesenian tradisional Indonesia ditampilkan dalam acara tersebut. Kesenian dari Sunda seperti lagu-lagu tradisional, kesenian khas Tapanuli, Tari Piring, hingga Tari Serimpi, turut dipertunjukkan pada kesempatan berharga itu. Acara ini pun mendapat sambutan yang luar biasa dari tamu undangan.

Upaya Hurustiati berhasil menarik rasa ingin tahu orang-orang Barat, terutama yang berada di Inggris, mengenai kebudayaan Indonesia. Oleh karena itu, Kedutaan Besar Indonesia di London membuka pameran yang permanen di London. Pembukaan pameran tersebut dilakukan oleh 
Handep Jurnal Sejarah dan Budaya Vol. 5, No. 1, Desember 2021, hlm. 1-26

Hurustiati Soebandrio pada Desember 1953, di kantor kedutaan RI (Singapore Standard 25 Desember 1953:9). Keberadaan pameran tersebut tentu sangat mendukung diplomasi Indonesia di Inggris, bahkan di Eropa secara keseluruhan. Bagaimanapun, harus disadari bahwa aspek sosial dan kebudayaan juga turut menentukan keberhasilan upaya diplomasi suatu negara dengan negara lainnya.

Selain membntuk citra Indonesia sebagai negara yang kaya akan kebudayaan dan memiliki kesadaran kesetaraan gender, Hurustiati Soebandrio juga membentuk citra Indonesia sebagai negara yang kaya akan kuliner. Hal ini diperlihatkan oleh Hurustiati dengan aksinya turun langsung dalam pameran makanan yang diselenggarakan di Inggris. Pada November 1953, Federasi Pelajar Perempuan di Inggris menyelenggarakan sebuah pameran kuliner internasional di Balaikota Chelsea (De Nieuwsgier 14 November 1953). Kesempatan tersebut tidak disia-siakan oleh Hurustiati Soebandrio yang saat itu masih berada di London. Hurustiati Soebandrio kemudian mengajak perempuan-perempuan Indonesia yang berada di London untuk ikut serta mempersiapkan lokasi khusus Indonesia dalam pameran tersebut.

Dalam pelaksanaan pameran, Hurustiati Soebandrio bersama beberapa perempuan Indonesia memakai pakaian khas Indonesia, serta menjual makanan khas Indonesia. Beberapa makanan yang berhasil menarik perhatian pengunjung pameran antara lain kerupuk udang dan gethuk (Algemeen Indisch Dagblad de
Preangerbode 16 November 1953). Popularitas makanan khas Indonesia tersebut patut dibanggakan, mengingat makanan tersebut bersaing dengan makanan dari berbagai negara seperti Thailand, India, Ceylon (Srilanka), Australia, Prancis, Jerman, Swedia, dan beberapa negara lainnya (Algemeen Indisch Dagblad de Preangerbode 16 November 1953). Keseriusan Hurustiati Soebandrio dalam membentuk dan memperkenalkan citra Indonesia sebagai negara yang kaya akan kuliner lezat tersebut tidak hanya terlihat dari kemauannya untuk turun langsung mempersiapkan pameran. Ketika pameran berlangsung, Hurustiati Soebandrio bahkan turun langsung sebagai kasir di lokasi yang telah disiapkan (De Nieuwsgier 14 November 1953).

Keberhasilan Hurustiati Soebandrio dalam membentuk citra Indonesia sebagai negara yang kaya akan kuliner lezat kemudian meningkatkan minat orang-orang di Inggris terhadap kuliner Indonesia. Dalam rangka memeriahkan Natal pada akhir 1953, Hurustiati kembali memperkenalkan kuliner Indonesia. Upaya tersebut masih berlangsung hingga awal Januari 1954. Bahkan pada Januari 1954, Hurustiati berani menawarkan gethuk kepada Nyonya Nancy Astor, tokoh kelahiran Amerika yang menjadi perempuan pertama di parlemen Inggris (Daily Examiner 4 Januari 1954:3). 


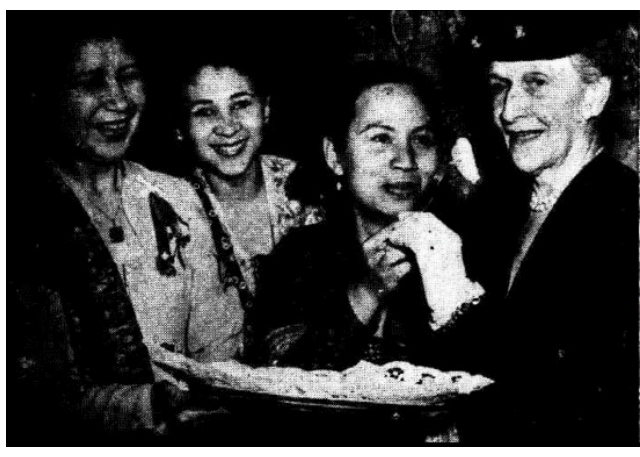

Gambar 4. Hurustiati Soebandrio ketika memperkenalkan dan menawarkan gethuk kepada Nancy Astor di Chelsea Town Hall. Sumber: https://trove.nla.gov.au/newspaper.

Meskipun peranan Hurustiati tampak hanya pada persoalan menginisiasi dan menyiapkan pameran, ataupun mengajak komunitas Indonesia di Inggris untuk memperkenalkan kebudayaan Indonesia, akan tetapi perlu ditekankan bahwa upaya tersebut menjadi sangat bernilai pada masa awal kemerdekaan hingga setidaknya sampai pertengahan dekade 1950an. Upaya Hurustiati dalam membentuk citra Indonesia sebagai negara yang mencapai kesetaraan gender, kaya akan kebudayaan dan kuliner, hingga potret Indonesia sebagai negara yang merdeka dan berdaulat menjadi semakin bernilai ketika hal-hal tersebut diletakkan dalam peta sosial politik internasional pada periode yang sama. Tanpa bermaksud melebih-lebihkan peran Hurustiati, agaknya wajar untuk menyebutkan bahwa ia telah turut berkontribusi dalam menampilkan citra baik Indonesia di luar negeri, terutama di Inggris, ketika polarisasi akibat Perang Dingin semakin tajam. Pada saat itu, tentu menjadi penting bagi sebuah bangsa dan negara, apalagi Indonesia yang belum lama memproklamirkan kemerdekaannya, untuk membentuk dan menguatkan identitasnya dalam percaturan politik dan diplomasi internasional. Hal ini disebabkan oleh bahaya Perang Dingin yang tidak jarang dapat merusak identitas suatu negara yang telah merdeka, terutama negaranegara bekas jajahan.

Sementara itu, upaya Hurustiati Soebandrio dalam membentuk citra Indonesia di Inggris, terutama di lingkungan diplomatik, bukan berarti tanpa hambatan. Nyonya Roeslan Abdulgani dalam catatannya menyebutkan bahwa Hurustiati Soebandrio pernah menceritakan kehidupan dan lingkungan para diplomat di Inggris. Menurut Hurustiati, lingkungan diplomatik di Inggris merupakan lingkungan yang sangat kaku (Abdulgani 1954: 53). Karenanya, tidak mudah bagi Hurustiati untuk memperkenalkan citra baik Indonesia di Inggris. Apalagi pada saat yang sama, kondisi politik sangat fluktuatif, dimana Indonesia masih terlibat perdebatan sengit dengan Belanda mengenai masalah Irian Barat. Masalah tersebut berkali-kali menjadikan Indonesia dituduh sebagai negara yang mengkolonisasi Irian Barat. Dengan adanya permasalahan semacam itu, maka tugas Hurustiati dalam membentuk sekaligus memperkenalkan citra Indonesia di Inggris semakin berat. Namun, berbagai sumber menyebutkan bahwa Hurustiati berhasil melewati tantangan tersebut. Hal ini tidak lain didorong oleh kecerdasan sekaligus sikapnya yang hangat dan pandai bergaul dengan kalangan pejabat diplomatik di Inggris. Selain itu, upaya tersebut juga tidak dapat dilepaskan dari kelincahan Soebandrio dalam melakukan diplo- 
Handep Jurnal Sejarah dan Budaya Vol. 5, No. 1, Desember 2021, hlm. 1-26

masi dan bergaul dengan semua kalangan bahkan kalangan Istana Buckingham sekalipun. Bagaimanapun, hal tersebut juga mendorong keberhasilan Hurustiati untuk memperkenalkan kebudayaan, kuliner, hingga citra Indonesia sebagai negara merdeka di hadapan petinggi-petinggi diplomatik yang ditempatkan di Inggris.

Upaya Hurustiati Soebandrio dalam membentuk dan memperkenalkan citra Indonesia di Inggris berakhir pada tahun 1954, bersamaan dengan berakhirnya masa tugas Soebandrio. Selanjutnya, ia harus menemani Soebandrio menjalankan tugasnya sebagai Duta Besar di Moskow, Rusia. Pada dasarnya, upaya Hurustiati selama di Inggris menjadi bagian yang paling krusial dari perjalanannya sebagai istri diplomat Soebandrio, terutama dalam hal membentuk dan memperkenalkan citra Indonesia di luar negeri. Peran Hurustiati tentu tidak dapat diabaikan begitu saja, sebab bagaimanapun upayanya membentuk citra baik Indonesia turut memudahkan misi diplomasi Indonesia pada periode yang sama, maupun pada periode selanjutnya. Apalagi, Hurustiati melakukan halhal tersebut di Inggris, negara yang bahkan pada masa revolusi kemerdekaan cenderung pro terhadap Indonesia (Cheong 2013:36).

Atas peranannya terhadap Republik Indonesia, termasuk ketika bertugas menemani Soebandrio selama menjadi diplomat, Hurustiati pun mendapat pujian dari Presiden Soekarno. Hal ini ditampakkan oleh Presiden Soekarno ketika berpidato pada Rapat Umum Hari Wanita Internasional tahun 1966.
Bahkan, Presiden Soekarno menyatakan kesepakatannya dengan pandangan Hurustiati Soebandrio, bahwa tugas seorang perempuan bukan saja bertanggungjawab atas keluarga ataupun anak-anaknya, tetapi juga atas keberlangsungan bangsa dan negara Indonesia (Sekretariat Negara 1966). Selain itu, peran yang sangat penting dari Hurustiati juga turut mendukung keberhasilan figur Soebandrio sebagai seorang diplomat. Bahkan, diplomat dari luar negeri tidak jarang menyebut Soebandrio sebagai salah satu diplomat terbaik pada masanya.

\section{SIMPULAN}

Hurustiati Soebandrio merupakan salah satu tokoh perempuan yang berperan dalam pembentukan citra Indonesia di luar negeri. Perannya tersebut tidak lain didorong oleh posisinya yang memang merupakan istri dari seorang diplomat sekaligus Duta Besar yakni Soebandrio. Sepanjang menemani Soebandrio berkarir sebagai diplomat, periode 1947 sampai 1954 menjadi masa yang paling penting dalam proses pembentukan citra Indonesia di luar negeri oleh Hurustiati Soebandrio. Hal ini dikarenakan periode tersebut sangat penting bagi Indonesia, dimana pada 1947 sampai 1950 Indonesia perlu mendapatkan perhatian internasional agar dapat mempertahankan kemerdekaan, dan periode 1950 sampai 1954 dimana Indonesia perlu menampilkan citranya di kancah diplomatik internasional.

Mengingat pentingnya menunjukkan citra baik Indonesia, Hurustiati Soebandrio melakukan berbagai upaya di Inggris sejak tahun 1947. Citra 
Indonesia dalam hal ini dapat dimaknai sebagai sebuah nation branding, di mana Indonesia divisualisasikan melalui berbagai elemen unik yang dimilikinya, seperti kebudayaan. Citra (image) ini sangat penting untuk dibentuk di kancah global, apalagi bagi negara yang tergolong baru seperti Indonesia. Bagaimanapun, citra negara yang dibentuk dengan baik akan memberikan keuntungan yang kompetitif bagi Indonesia, baik dari sisi politik, ekonomi, maupun dalam kehidupan sosial sebagai anggota komunitas global. Secara umum, ada tiga citra Indonesia yang digambarkan oleh Hurustiati Soebandrio, yakni citra Indonesia sebagai sebuah negara bangsa yang merdeka, Indonesia sebagai negara yang kaya akan kebudayaan, serta Indonesia sebagai negara yang mengakui kesetaraan gender. Bagaimanapun, unsur kesetaraan gender menjadi sangat penting dalam promosi citra baik Indonesia dimana kesetaraan gender turut menjadi salah satu simbol bahwa suatu negara telah mencapai kemapanan.

Untuk membentuk citra Indonesia dengan tiga ciri di atas, maka Hurustiati Soebandrio melakukan berbagai upaya. Mulai dari memberikan ceramah tentang emansipasi perempuan Indonesia, menyelenggarakan pameran kebudayaan, hingga memperkenalkan kuliner Indonesia kepada tokoh-tokoh pejabat tinggi di Inggris, semua itu dilakukan oleh Hurustiati Soebandrio. Meskipun pada kenyataannya, tidak mudah baginya untuk melakukan pembentukan citra Indonesia sebaik mungkin. Akan tetapi, Hurustiati Soebandrio berhasil melalui berbagai tantangan yang ada. Perannya pun turut menjadi salah satu faktor keberhasilan diplomasi Soebandrio selama berada di Inggris. Keberhasilan ini ditandai dengan terjalinnya hubungan diplomatik dan kerja sama ekonomi dengan Inggris, meningkatnya kepercayaan masyarakat dan pemerintah Inggris terhadap Indonesia terutama pada masa revolusi, hingga respons komunitas internasional di Inggris yang menunjukkan ketertarikannya terhadap budaya dan adat istiadat Indonesia. Hal ini tentu memberikan legitimasi bagi Indonesia untuk terus membentuk dan menampilkan citranya di kancah internasional.

Paparan mengenai peran Hurustiati Soebandrio dalam makalah ini membuktikan bahwa perempuan dapat memberikan sumbangan penting bagi negara. Tak hanya itu, makalah ini juga merefleksikan pentingnya kehadiran istri atau perempuan bagi elite nasional yang tengah memperjuangkan kepentingan republik pada masanya. Karenanya, benarlah ungkapan bahwa di balik kesuksesan laki-laki, ada perempuan tangguh di belakangnya. Penggunaan ungkapan ini tentu bukan bermaksud untuk melakukan glorifikasi terhadap peran Hurustiati Soebandrio, melainkan cukup menjadi refleksi bahwa dalam sejarah perjalanan bangsa Indonesia, para perempuan telah menorehkan catatan kontribusinya masing-masing. 
Handep Jurnal Sejarah dan Budaya Vol. 5, No. 1, Desember 2021, hlm. 1-26

\section{DAFTAR SUMBER}

Abdulgani, Roeslan (Ny.). 1954. "London: Ibukota Negara Dewasa". Majalah Wanita Vol. 6, No. 3, Februari, 5.

Algemeen Indisch Dagblad de Preangerbode. 16 November 1953. Diunduh 9 Desember, 2020 (www.delpher.nl).

Algemeen Dagblad. 4 April 1964. Diunduh 9 Desember, 2020 (www.delpher.nl).

Amini, Mutiah. 2021. Sejarah Organisasi Perempuan Indonesia. Yogyakarta: Gadjah Mada University Press.

Anholt, Simon. 2013. "Beyond the Nation Brand: The Role of Image and Identity in International Relations". Exchange: The Journal of Diplomacy 2(1): 1-7.

Anonim. 1951. "Pidato Nyonya Dr. Hurustiati Subandrio. Dunia Wanita. Vol. 10, No. 2, Juni.

Anonim. 1953. "Puspa Ragam Penerangan". Mimbar Penerangan. Vol. 4, No. 7, Juli.

Anonim. 1954. "Di Luar Negeri, Apa Djasa Mereka?". Majalah Wanita. April

ANRI. 1950. Inventaris Arsip Sekretariat Negara Seri Produk Hukum 1949-2005, No. 4638. "Keputusan Presiden Republik Indonesia Serikat Nomor 87 Tahun 1950 tentang Pengangkatan Dr.
Subandrio sebagai Duta Besar Luar Biasa dan Berkuasa penuh pada Pemerintah Kerajaan Inggris".

Anwar, Rosihan. 2009. Sejarah Kecil Petite Histoire Indonesia. Jilid II. Jakarta: Kompas.

Anwar, Rosihan. 2011. Sutan Syahrir: Negarawan Humanis, Demokrat Sejati yang Mendahului Zaman. Jakarta: Kompas.

Armstrong, Elisabeth. 2016. "Before Bandung: The Anti-Imperialist Women's Movement in Asia and the Women's International Democratic Federation". Signs: Journal of Women in Culture and Society 41(2): 305-331.

Blackburn, Susan. 2004. Women and the State in Modern Indonesia. Cambridge: Cambridge University Press.

Cheong, Yong Mun. 2003. The Indonesian Revolution and the Singapore Connection. Leiden: KITLV Press.

Chipp, Sylvia A., dan Justin J. Green. 1980. Asian Women in Transition. Pennsylvania: Pennsylvania State University.

Daily Examiner. 4 Januari 1954. Diunduh 12 Desember, 2020 (https://trove.nla.gov.au/ newspaper).

De Nieuwsgier. 22 Januari 1953. Diunduh 9 Desember, 2020 (www. delpher.nl). 
De Nieuwsgier. 14 November 1953.

Diunduh 9 Desember, 2020 (www. delpher.nl).

De Volkskrant. 16 April 1974.

Departemen Kesehatan RI. 1980. Sejarah Kesehatan Nasional Indonesia Jilid II. Jakarta: Departemen Kesehatan RI.

Dinnie, Keith. 2008. Nation Branding: Concepts, Issues, Practices. Burlington: Elsevier.

Dhita, Aulia Novemy. 2020. "Studi Historis Sekolah Kedokteran di Indonesia Abad XIX". Jurnal Agastya 10(2):180-196.

Het nieuws van den dag voor Nederlandsch-Indie. 25 Agustus 1937.

Indian Daily Mail. 27 Januari 1952. HIm. 3. Diunduh 10 Desember, 2020 (https://eresources.nlb.gov.sg/ newspapers/).

Indian Daily Mail. 22 Maret 1950. Hlm. 3.

Jones, Howard Palfredy. 1971. Indonesia: The Possible Dreams. New York: Harcourt Brace Javanovich Inc.

Kuntowijoyo. 2013. Pengantar Ilmu Sejarah. Yogyakarta: Penerbit Tiara Wacana.

Leifer, Michael. 1989. Politik Luar Negeri Indonesia. Jakarta: Gramedia.
Lewis, Reba. 1963. Indonesia: Troubled Paradise. New York: David McKay Company.

Lindsay, Jennifer. 2012. "Performing Indonesia Abroad". Hlm. 191-220 dalam Heirs to World Culture: Being Indonesian 1950-1965, disunting oleh Jennifer Lindsay, dan Maya H. T. Liem. Leiden: KITLV Press.

Malaya Tribune. 27 Mei 1950. Hlm. 1.

Minarova-Banjac, Cindy. 2018. "Gender Culture in Diplomacy: A Feminist Perspective". Culture Mandala 13 (1).

Moritz, Charles (ed.). 1963. Current Biography Yearbook, 1964. New York: The H. W. Wilson Company.

Nash, Philip. 2020. Breaking Protocol: America's First Female Ambassadors, 1933-1964. Lexington: The University Press of Kentucky.

Ningrum, Alvi Dwi dan Pradipta Niwandhono. 2013. "Peran PRRI dalam Pertempuran Surabaya Tahun 1945". Verleden: Jurnal Kesejarahan 3(1): 77-88.

Panitia Penulisan Sejarah Diplomasi Republik Indonesia. 1996. Sejarah Diplomasi Republik Indonesia Dari Masa Ke Masa. 4 Jilid. Jakarta: Deplu RI.

Papachristou, Judith. 1990. “American Women and Foreign Policy, 18981905: Exploring Gender in 
Diplomatic History". Diplomatic History 14(4): 493-509.

Pranoto, Suhartono W. 2001. Revolusi Agustus: Nasionalisme Terpasung dan Diplomasi Internasional. Yogyakarta: Lapera Pustaka Utama.

Quiko, Edo. April-Juni 1972. "The Political Trial of Raden Subandrio in Indonesia". Asian Forum 4(2): 49-60.

Radjasa, Kartini Karna. 14 Februari 1958. "Menyambut Konferensi Wanita Asia Afrika I". Suluh Indonesia.

Ricklefs, M. C. 2008. Sejarah Indonesia Modern 1200-2008. Jakarta: Penerbit Serambi.

Sekretariat Negara. 1966. “Amanat P.J.M. Presiden Sukarno pada Rapat Umum Hari Wanita Internasional di Istora Senayan Jakarta, 8 Maret 1966". Dalam Arsip Kabinet Presiden RI. Diunduh 8 Desember 2020 (https:/ /repository.monash.edu/).

Singapore Standard. 25 Desember 1953. Diunduh 10 Desember, 2020 (https://eresources.nlb.gov.sg/ newspapers/).

Soebandrio. 2001. Kesaksianku Tentang G-30-S. Jakarta: Forum Pendukung Reformasi Total.

Star Weekly. 20 September 1952. Hlm.14-15.
Sujud, T. Juli 1954. "Pertemuan dengan Ny. Subandrio". Wanita. Hlm. 358.

The Chronicle. 12 Juni 1952. Hlm. 28. Diunduh 12 Desember, 2020 (https://trove.nla.gov.au/ newspaper).

The Singapore Free Press. 22 Maret 1951. Diunduh 10 Desember, 2020 (https://trove.nla.gov.au/ newspaper).

The Tatler. 30 April 1952. Hlm. 29. Diunduh 9 Desember, 2020 (https://www.britishnews paperarchive.co.uk/).

Vreede-de Stuers, Cora. 2017. Sejarah Perempuan Indonesia: Gerakan dan Pencapaian. Depok: Komunitas Bambu.

Wieringa, Saskia Eleonora. 2010. Penghancuran Gerakan Perempuan: Politik Seksual di Indonesia Pascakehancuran PKI. Yogyakarta: Galang Press.

Wood, Molly M. 2015. "Wives, Clerks, and 'Lady Diplomats': The Gendered Politics of Diplomacy and Representation in the U.S. Foreign Service, 1900-1940". European Journal of American Studies 10 (1): 1-13.

Wulandari, Ayu. 2020. "Kaum Perempuan dalam Diplomasi Kebudayaan Indonesia, 1945 1960an." Jurnal Penelitian Sejarah dan Budaya 6 (2): 319-342. 
Wulandari, Ayu. 2021. "Di Balik

Meja Perundingan: Tiga Diplomat

Perempuan dalam Misi Diplomasi

Indonesia (1946-1960an)". Skripsi.

Departemen Sejarah, Fakultas Ilmu

Budaya, Universitas Gadjah Mada. 

Vol. 5, No. 1, Desember 2021, hlm. 1-26 